DOI: https://doi.org/10.47405/mjssh.v5i4.386

\begin{tabular}{|c|c|}
\hline 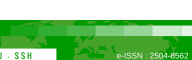 & Malaysian Journal of Social Sciences and Humanities (MJSSH) \\
\hline $\begin{array}{l}\text { Malaysian Journal of } \\
\text { Social sciences and }\end{array}$ & Volume 5, Issue 4, April 2020 \\
\hline $\begin{array}{l}\text { (Mumantites } \\
\text { (MJ-sSH) }\end{array}$ & e-ISSN : 2504-8562 \\
\hline & $\begin{array}{l}\text { Journal home page: } \\
\text { www.msocialsciences.com }\end{array}$ \\
\hline
\end{tabular}

\title{
Using Rhetorical Approach of Ethos, Pathos and Logos by Malaysian Engineering Students in Persuasive Email Writings
}

\author{
Isai Amutan Krishnan', Teoh Mei Lin1, Hee Sio Ching², Selvajothi Ramalingam1, Elanttamil \\ Maruthai ${ }^{1}$ \\ 1Faculty of Languages and Linguistics, University of Malaya (UM) \\ ${ }^{2}$ HELP University
}

Correspondence: Isai Amutan Krishnan (amuthan.isai@gmail.com)

\begin{abstract}
It seems that many English language learners have deficiency to write persuasively. This portent has been observed among university students, particularly those from technical fields. Therefore, the present study examines the use of ethos, pathos and logos in persuasive email writing and determines if these features were used appropriately. The participants involved in this research were 43 third-year Malaysian engineering students. The task evaluated was persuasive email writing, and the data was obtained from an official university website forum. The data was analysed qualitatively by using Aristotelian rhetorical theory. The results show that there were some persuasive techniques used by the students in their email writing. It appears that the appeal to pathos was preferred highly in directly connecting with the emotions of the instructors. This was followed by appeals to ethos, where the students used their own ethicality and credibility to persuade the instructor into giving them an extension deadline of their classwork. The findings further revealed that appeal to logos were not used in a very persuasive manner, which could also due to avoiding logical fallacies. Therefore, the present study shows the engineering students prefer to link with emotions in their email writing in achieving their goals.
\end{abstract}

Keywords: persuasive email, ethos, pathos, logos, engineering students

\section{Introduction}

Persuasion is often employed in spoken and written forms of communication. In writing, the use of emotion and logic tend to demonstrate pleasant in persuasion. With the rapid development of modern technologies, spoken and written persuasive abilities are being eroded day by day among millennial students (Koo, Gretzel, Hunter, \& Chung, 2015). Nicks (2015) noted that the art of persuasion is most often acquired through interactive communication. Nicks mentioned that most millennial students have been influenced by psychological or social factors in the deterioration of their persuasive skills stemming from communicating indirectly with interlocutors through electronic devices via social media websites and software applications such as WhatsApp, WeChat, Instagram, and Facebook. Thus, their abilities to express feelings have been diminished because of the lack of direct human interaction in such contexts, which could explain why millennial students demonstrate poor abilities in the persuasive arts. Hence, this research focused on the persuasive writing of millennial engineering students born in the year 2000 (Horovitz, 2012; Jennifer \& Jorge, 2018). 
Persuasive writing is a form of non-fiction writing comprised of careful word choice, the development of logical arguments, and cohesive summarisation. The practice of this type of writing may serve to help writers in developing specific reasons for their opinions and provides opportunities to research facts related to their opinions. For persuasive writing to be effective, writers need to clearly state their opinions and then provide ample evidence to support their ideas. In the context of language learning, students could be trained to write persuasively with the aim of convincing their readers. Instructional assignments could take the form of writing a five-paragraph essay with the introduction of an issue or problem, continuing with an explanation of the issue or problem, an explanation of how the problem affects the readers, and closing with a call to action. Finally, some explanation may be provided to the reader on how to overcome the issue or problem in an effort to influence the readers' actions or thoughts (Sung-Byung, Hanna, Kyungmin, \& Chulmo, 2018).

However, persuasive writing is not an easy skill to master. It appears that many language learners lack the ability to write persuasively. This phenomenon has been observed among university students, especially those from technical fields such as engineering (Frank, 2018; Graham, Harris, \& Mason, 2005). Previous studies have argued that what is of concern is that the writing genre these technical students have been used to typically does not involve persuasive argumentation nor elements specifically used in convincing readers, as in the portrayal of credibility (Jennifer \& Jorge, 2018).

Pertaining to persuasive writing, Aristotle's (384-322 BCE) rhetoric has been the mainstay for 2500 years. Aristotle's principles of persuasion were derived from his observations of speeches, and today his principles form the theoretical foundation for research on persuasive discourse in different contexts (e.g., Berlanga, García-García, \& Victoria, 2013; Emanuel, Rodrigues, \& Martins, 2015). To date, studies using Aristotle's concepts of rhetoric have shown that pathos (emotion) is used more than logos (reason) in persuasive discourse, and ethos (credibility) is the least used, subject to cultural variations. The information that is available has been obtained mainly from formal written documents such as complaint letters (Al-Momani, 2014), argumentative essays (Uysal, 2012), advertisements (Abdul Rashid, Jamal, Ibrahim, Yunus, Azmi, Anas, Mohamed, 2016; Nair \& Ndubisi, 2015) and social media communication (e.g., Androniciuc, 2016, Emanuel et al., 2015; Fife, 2010; Shahrbanou, Helen, Ain Nadzimah Abdullah, Sharon \& Lee, 2019). However, only a few studies have examined rhetorical appeals in email writing; therefore, this study seeks to investigate how learners use such strategies to persuade their readers in this genre.

Persuasiveness is evident in situations where requests are granted based on strong arguments. A study was done on this by Chakorn (2006), who conducted a contrastive analysis of the rhetoric of 80 authentic letters of request written in English by Thai speakers and native English speakers in the Thai business context. Chakorn's (2006) findings showed culture-specific differences in the use of persuasive strategies in that the Thai speakers wrote letters of request using a combination of logos, ethos and pathos, whereas the native English speakers' letters were logos oriented. Chakorn's (2006) results are supported by other studies on rhetoric in persuasive discourse. In another study which examined complaint letters, there was evidence of the use of strong logos by American writers compared to the Japanese writers (AlMomani, 2014).

As for technical proposals, the goal of writing is to obtain approval. Beck and Wegner (1992) found that it is relevant to focus on the ethos mode of persuasion to increase the persuasiveness of a proposal, but it is not appropriate to use pathos. The requests studied by Beck and Wegner (1992) and Chakorn (2016) are on the more formal end of the continuum involving written requests.

Persuasive email writing is an area of study that has not been given much attention, yet this genre is important because email is often used to achieve important goals. In a university context, an example of formal persuasive email writing could involve making requests for an appointment, a change of class, or an assignment deadline extension. The likelihood of having requests granted may depend on the writer's ability to use rhetorical appeals, subject to university rules and regulations. The university context offers the space for students to learn how to make effective requests, which would lead to successful communication in the workplace upon graduation. With this in mind, research was 
conducted to examine if the use of appeals employing ethos, pathos and logos in persuasive email writing was appropriate among engineering students in one of the local Malaysian universities.

\section{Literature Review}

Burke (1969) states that "wherever there is persuasion, there is rhetoric. And wherever there is meaning, there is persuasion" (p. 72), and this is indeed an apt statement to emphasize the persuasiveness of rhetoric. Rhetoric exists in every kind of communication and has persuasion at its core. Scholars from different research fields have been exploring various theories and explanations related to persuasion in communication throughout the centuries, including Burke's (1945) analysis of "pentad," Black's (1970) analysis of "second persona" and Charland's (1987) analysis of constitutive rhetoric. Most of their studies were "derived from the work of Aristotle in some way or another" (Larson, 1992, p. 61).

Rhetoric is defined as "an ability, in each particular case, to see the available means of persuasion" (Aristotle, 1954, p. 36). In order to effectively persuade the audience, three important persuasive appeals are identified - ethos, pathos and logos-corresponding to the persona of the speaker, the emotion of the audience, and the reason of the message. In the words of Aristotle:

Of the modes of persuasion furnished by the spoken word there are three kinds. The first kind depends on the personal character of the speaker; the second on putting the audience into a certain frame of mind; the third on proof, or apparent proof provided by the words of the speech itself. (Aristotle, 1954: On Rhetoric, translated by Roberts)

The major purpose of persuasive writing is to convince the reader that the ideas given are valid and more unique than others. Aristotle segmented the definition of appeals and persuasion into three classifications: ethos, pathos and logos. The definitions are provided in Table 1, below.

Table 1: Definition of Ethos, Pathos and Logos

\begin{tabular}{ll}
\hline Ethos & The art of convincing by the character of an author is referred to as Ethos (i.e. \\
credibility), or ethical appeal. There is a tendency of believing people whom we \\
respect. Projecting an impression to the reader that you are someone worth listening \\
to is one of the central problems of argumentation, in other terms placing yourself as \\
an author of an authority on the paper's subject, as well as a person who is both \\
worthy of respect and likable. \\
The art of persuading by means of appealing to the emotions of readers is referred to \\
as Pathos (i.e. emotional). Seeing how pathos, emotional appeals, are used to \\
persuade can be based on texts ranging from classic essays to contemporary \\
advertisements. An audience's emotional response can be affected by the choice of \\
language, and an argument can be enhanced through the use of an effective emotional \\
appeal. \\
Logos (i.e. logical) refers to a reasoning-based persuading. Deductive and inductive \\
reasoning shall also be considered, as well as the discussion of what leads to a \\
persuasive as well as an effective reason for the backup of claims. The heart of \\
argumentation is based on 'giving reasons', and it cannot be over-emphasised. Kinds \\
of support that could be used to authenticate a thesis shall be studied, as well as \\
consideration of some logical fallacies that are common, in order to avoid them while \\
writing.
\end{tabular}

Source: Aristotle's Rhetoric (1959)

The basis of this study's theoretical framework is Aristotle's conceptualisation of rhetoric. In brief, Aristotle viewed rhetorical appeals to ethos (credibility), pathos (emotion) and logos (reason) as means of persuasion. As Aristotle did not specify the analysis procedures for persuasive communication (Higgins \& Walker, 2012), researchers who made use of Aristotle's means of persuasion have 
constructed their own analysis frameworks based on the phenomenon being investigated. The three types of rhetorical appeals are described below.

Pathos is an emotional appeal and involves "putting the audience into a certain frame of mind" (Demirdogen, 2010, p. 190). Pathos persuades by using security, love, guilt, greed, pity and humour (Gabrielsen \& Christiansen, 2010), anger, insult, empathy, fear and confusion (Mshvenieradze, 2013). In an emotional appeal, the speaker shows identification with the "needs, values and desires of the audience" (Higgins \& Walker, 2012, p. 198). Thus, a good persuasive writer should know which emotion to tap into, taking into consideration the social status, age and other characteristics of the audience (Mshvenieradze, 2013). To illustrate, in a study on complaint letters, Al-Momani's (2014) analysis identified the following as examples of persuasive techniques which appeal to emotions: confessing, regretting, making pleas, promising, praising, and thanking. Al-Momani (2014) explained that confession works by drawing on the audience's sympathy but praising and thanking work through manipulation of the audience's feelings to form rapport with the complainant (e.g., "I am sure of your wisdom"). Following praise and thanking, the student usually made a plea and a promise not to repeat the offensive action. Metaphors are also commonly used to appeal to the emotions of the audience.

Logos is a rational appeal, and persuasion is done using "the proof, or apparent proof, provided by the words of the speech itself" (Demirdogen, 2010, p. 190). Logos appeals to reason, which makes the "clarity and integrity of the argument" very important (Higgins \& Walker, 2012, p. 198). Demirdogen (2010, as cited in Hovland, Lumsdaine, and Sheffield, 1949) and Larson (1992) show that two-sided messages are more persuasive for more educated readers who might not agree with the message.

In a rhetorical analysis, the appeal to logos can be identified from the use of argumentation, logic, warrants/justification, claims, data, and evidence/examples. These are the substance of logical, rational, critical and analytical discourse. The appeal to reason in students' complaint letters analysed by AlMomani (2014) took the form of questioning, wondering and arguing. An example of a question that relies on reasoning is "How on earth can a person who had cheated get 10/40?" By using either questioning or wondering, the complainer distances himself/herself from the action. Argumentative discourse may use linguistic links such as "initially," "later," and "finally" (Mshvenieradze, 2013, p.13).

Ethos, also known as ethical appeal, is an appeal to the personal character of the writer (Demirdogen, 2010). Ethos refers to the "persona, or projected character of a speaker/communicator, including their credibility and trustworthiness" (Higgins \& Walker, 2012, p. 197). For researchers intending to delve into the ethos appeal, it is important to distinguish between preliminary ethos (person-specific) and discourse (situation-specific) ethos. This was highlighted by a renowned linguist, Ruth Amossy (second part of 20th century in 1987). Preliminary ethos is the preliminary knowledge of the audience about the writer, in other words, what they know about the writer's authority, marital status and social status. Some writers attempt to ground on it and use such ethos in their favour during a discourse if it is positive. But if preliminary ethos is negative, the writer does his/her best to dispel such an impression of him/her. As for discourse ethos, it is the ethos created immediately for the specific situation and during the discourse (Amossy, 2000, p. 63, as cited in Mshvenieradze, 2013, p. 1940).

When it comes to choosing the best of three types of proof, Aristotle (1954, p. 1356a) explains, "[m]oral character, so to say, constitutes the most effective means of proof" (as cited in Mori, 2016, p. $65)$. However, the studies reviewed in the introduction section have shown that the ethos dimension of argumentative persuasion is the least popular in various kinds of persuasive discourse.

\section{Past studies on ethos, pathos and logos}

Apparently, no research dealt with using ethos, pathos and logos (Aristotle, 1954) in persuasive writing before 2000 (Demirdogen, 2010). Several studies have been done since 2010 which may provide a better understanding of the extent research as a basis for carrying out the present study. A number of these studies have postulated a convergence in using Aristotle's theoretical concepts. Winn (2000) 
concurs on the key role of pathos in the persuasive power of Web design in e-business. In the context of public service advertisements on health, Robberson and Rogers (1988) found that "the traditional negative appeals to health may be more persuasive than positive appeals [and that] people may be persuaded to adopt healthy lifestyles for reasons other than health per se (i.e., to enhance self-esteem)" (p. 277).

In Uysal's (2012) study, 18 Turkish native speaker adults living in the United States wrote essays in both Turkish and English. The use of Aristotle's rhetorical appeals was similar in Turkish and English for $89 \%$ of the participants. The most frequently used rhetorical appeal was logos, used by $72 \%$ of participants in both their essays. However, more participants used logos as a primary appeal when they wrote Turkish essays (94\%) compared to English essays (67\%). Since the participants wrote both Turkish and English essays, Uysal's (2012) results showed that the language in which the argumentative essay is written influenced the rhetorical appeal used, and this is indicative of cultural influence.

Al-Momani (2014) analysed 100 complaint letters from two Jordanian universities and found that appeal to pathos was the most prevalent persuasion strategy. The second most frequently used persuasion strategy was ethos for private university students and logos for public university students. In their complaint letters, the students resorted to socio-cultural values to achieve their goal for all three types of persuasion strategies. For example, they used religious borrowings, reference to health problems and sickness of parents as excuses for missing classes. Al-Momani (2014) did not find gender difference in the use of persuasion strategies. There are, however, cultural differences in use of rhetorical appeals. Americans prefer rational appeals (logos), whereas Japanese prefer affective appeals (pathos) (Kamimura \& Oi, 1998; Okabe, 1983, as cited in Uysal, 2012).

The above studies do not represent the full extent of the research on these rhetorical devices, however. Interestingly, there was another study on rhetorical appeals in requests present in complaint letters submitted to institutions of higher education that yielded similar results on cultural variation. Karatepe (2016) found that the Turkish learners of English were more inclined to omit an explicit request than native speakers of English, thinking that the readers of the complaint letters could interpret their request from the explanation of the problem.

Interestingly, there were two recent studies conducted by Ting (2018) on ethos, logos and pathos in university students' informal requests and Ting and Collin (2018) on framing of disease risk messages in airport banners. Ting (2018) investigated the university students' strategies of persuading their lecturer to grant their requests. It was found that pathos appeals were used the most. The data were from 165 students enrolled in an English language course in a Malaysian university. They were asked to write down what they would say to persuade their lecturer to end class early. Some students used more than one strategy, giving rise to 180 persuasion strategies in total. Analysis of their requests showed that a majority of the students used one type of rhetorical appeal to persuade. Emotional appeal (pathos) was the most popular persuasion strategy, accounting for over half of the persuasion strategies identified, followed closely by the rational appeal (logos). Appeal to ethos (credibility) was seldom used. The results suggest that students could benefit from the teaching of persuasive discourse so that they are able to use rhetorical appeals more effectively. In view of all these contributions, the present study can provide a clearer representation of persuasive email writing.

Ting and Collin's (2018) studies were similar to Lisa's (2016) studies in the conclusion that persuasive skills should be integrated with appraisal skills and that persuasive presentation skills which appeal to ethos, pathos and logos should be considered as academic skills, as well. Ting and Collin's study didn't end there. It was continued with research on framing and persuasiveness, as discussed below.

This current study is intended to explore the above mentioned rhetorical devices and obtain findings lacking from the previous studies discussed above. Research has reported that the concepts of persuasion related to ethos, pathos and logos can be used to characterise rhetoric used in persuasive email writings in persuading recipients to grant favours (Berlanga, Garcia-Garcia, \& Victoria, 2013); however, no study has attempted to examine the influence that the use of persuasive rhetoric has on 
information dissemination or gained an understanding of which, if any, of the rhetorical uses of ethos, pathos and logos produces the greatest response in persuasive email writings. Little research has been conducted to understand the impact of these rhetorical devices on persuasive behaviours and rhetoric. Therefore, it is the aim of this study to learn how these three categories of persuasion are effective in persuasive email writing and address this research gap through the characteristics of ethos, pathos and logos in persuasive email written by engineering students at a tertiary institution.

\section{Methodology}

\section{Research design}

Consent was obtained for conducting the research from the students, lecturers and administration body for ethical clearance. This study, which investigated the use of rhetoric in persuasive email writing, adopted a qualitative approach to the analysis of writing (Berg \& Lune, 2012). Therefore, the data was collected using two different approaches: collection of written samples and observation. Berg and Lune (2012) explained that if any written and observation data have been collected based on context, it is reliable and can be analysed qualitatively.

\section{Instrumentation}

\section{Written task}

In the public institution where the study was conducted, students from the engineering faculty had to undergo three semesters of three different English language classes to build their proficiency in the language, and each semester consisted of 14 weeks. The courses were the first semester's English for learning, second semester's English for Communication and the third semester's English for Professional and Various Text Writing, persuasive writing being included in the third semester. For this study, a class of these students $(\mathrm{N}=43)$ took part in the project/study. These participants obtained Band 4 in the Malaysian University English Test (MUET). These students were millennials born in the year 2000 and from various demographic backgrounds. In English for professional and various text writing, three assignments were involved. The first and second assignments were based on argumentative writing pertaining to articles which were downloaded from the open sources on current issues. The third assignment was to write a persuasive email based on a situation given by the instructor, as shown at the example below.

Dear Students,
(This is for a writing project)
Question
You are not able to submit your assignment as per deadline. Write an email to your instructor
and convince him/her to postpone the deadline. Your email should be persuasive with valid
reasons, and in not more than 80 words. You are required to write your email on the FORUM
ONLY.

For this study, the third assignment was used to gain information for the purpose of the study. The written persuasive emails were uploaded within a set time frame via the official University website in the forum column where assignments were uploaded. If the students failed to send their emails via the forum column within the set time, the written work would not reach the instructor on time. Brief and concise guidelines were also given to the students including the dos and don'ts of writing the third assignment. 


\section{Observation}

Observation was used in the present study (Atkinson \& Hammersley, 1994; Jorgensen, 1986) to obtain systematic and in-depth data to ensure how persuasively the students communicated consecutively in these three different classes, as mentioned, based on real classroom settings as Atkinson and Hammersley (1994) and Jorgensen (1986) noted that observation could be one of the specific sources of evidence in qualitative methodology, and it is an unobtrusive way of collecting data based on the context. The observation was done by three different English lecturers, who taught the same group (43 students) in three different English classes, as mentioned above. There common expected learning outcomes for the above courses were how the students wrote and spoke persuasively at the elementary, intermediate and advanced course levels. Therefore, observation was done over a 42 week period. As the third class mentioned above was the one in which the persuasive writing task was given, that class was thus suitable for collection of the data to confirm the lecturers' observations of the students were correct.

\section{Data collection}

The written data was collected from the university's official students' forum website. The written persuasive emails were downloaded from the forum column. The persuasive emails were analysed qualitatively using Aristotle's (1958) concepts of persuasion, which include ethos, pathos and logos. The data was tabulated and coded according to Aristotle's (1959) definitions (refer to Table 1). The method used for coding was based on an adaptation of Higgins and Walker's (2012) and Ting's (2018) work. The data were also verified by three academic staff members to ensure the data were tabulated and coded according to the study's parameters. They were in $90 \%$ agreement on the verification, which, according to Hayes and Krippendorff (2007), is an acceptable level of inter-rater reliability needed in qualitative analysis to ensure the data are reliable and valid.

\section{Findings and Discussion}

This sub-section provides examples of the engineering students' use of appeals to ethos, pathos and logos with the aim of persuading the instructor to extend the assignment deadline. The analysis has been divided into two categories, which are the strong and weak. While trying to make an appeal to ethos, some students displayed good character, credibility and strong convincing. Excerpt 1 shows examples of strong appeals to ethos.

\section{Excerpt 1}

ST4 Therefore, could you please kindly postpone the deadline so that I can submit it immediately? I apologise for any inconvenience caused and your help is much appreciated".

ST9 I promise that I will submit the assignment immediately to your office on 9th of December. I'm very sorry for any inconvenience caused. Thank you for your consideration.

ST14 can you please postpone the deadline for the submission date? I assure you I'll complete my assignment before the deadline".

ST27 I'm sorry that I am not able to submit the assignment on time. Instead, I would humbly ask for you to postpone the deadline slightly as my full recovery would be imminent. Thank you in advance.

ST32 I seek your sympathize that you can postpone the deadline to give me some time to recover. Your consideration is appreciated

ST36 "Hence, I would favourably request sir to extend my deadline once I am fully recovered and able to write again. Thanks for your understanding and consideration.

In excerpt 1, the students used different types of approach to persuade the instructor. Their main goal was to convince the instructor to give them an extension for the deadline of a due assignment. Their choice of words, 'kindly', 'please', 'humbly', 'favourably', and 'consideration', primarily depict their 
ethical appeals and make them sound very convincing. Moreover, the choice of words, 'apologise for inconvenience', 'assure', 'immediately', informs the instructor that they will finish the due work on time without causing more inconveniences. This possibly is hoped to leave a good impression and be highly likely to persuade the instructor. The next analysis is on weak appeals to the ethos.

Excerpt 2 (weak)

ST12 This is because the amount of time for this assignment is not sufficient due to my potential problems. I will complete this assignment with the help of my course mate"

ST22 I have no idea how to start it. Would it be possible for Sir to Postpone the deadline so I can come out with a better idea on how to do my assignment and able to submit it on time?"

ST29 I want to ask you to postponed the assignment submission deadline as the assignment contribute 40 percent of the final examination result

Excerpt 2 depicts a weaker appeal to ethos. The students were unable to provide a strong reason to obtain the extension. Their choice of words such as 'potential problems', 'no idea how to start it', 'want to ask you' were inappropriate, unprofessional and sounded impolite and vague. The phrase 'potential problems' did not go into proper detail and was indistinct because there could be many different problems the student might be dealing with. Furthermore, the phrase 'no idea how to start it' was a very clever way of getting the attention of the instructor, but it does not serve its intended persuasive purpose because it sounds bleak, signifying that the student is a procrastinator. If the student genuinely had difficulties in starting his/her work, he/she could have consulted the instructor earlier and not right before the due date. Moreover, the phrase 'want to ask you' sounds very impolite as if the student was imposing on the instructor and not requesting humbly. All these examples show weak character and credibility and are not convincing. Rather, they leave a poor impression.

In Excerpt 3, examples representing strong appeals to pathos are found.

Excerpt 3

ST2 I had gone through a surgery and need to take a rest for a week at the hospital. I hope that you would consider to postpone it by next week. I have to stay at the hospital for almost a week after my surgery for regular check-up

ST9 This is because my grandmother has passed away in this morning and I have to skip class to attend her funeral for this coming 5 days"

ST26 My mother where live on her own got no one to take care of her and I cannot turn blind eye towards her.

ST27 This is because i recently undergo surgery to my right arm and was sent into the ICU for 2 weeks. Due to wanting quick recovery, The doctor advised me to rest properly

ST32 I was involved in a serious accident last week and fractured my right shoulder. I am advised not to use my right arm until it is fully recovered"

Excerpt 3 involves strong emotions and a convincing appeal to pathos. Phrases used such as 'Gone through a surgery and need to take a rest for a week at the hospital', 'this is because my grandmother has passed away', and 'serious accident last week and fractured my right shoulder' appear convincing. These examples display how the students mentioned family members and themselves to persuade the instructor. Appeal to pathos could create an impact on the instructor as the situations are relatable. The examples also sound convincing because of the detailed explanation of the cause. It is assumed that if someone is sick, time is needed for recovery, and therefore assignments cannot be submitted on time. Hence, the instructor might be willing to offer an extension, and the students might then have successfully persuaded the instructor.

As opposed to the strong appeals to pathos, Excerpt 4 shows weak appeals to pathos.

\section{Excerpt 4}

ST7 I'm so sorry that I could not summit the assignment on time due to most of the tests are carried out this week and I'm not able to revise and complete the assignment at the same time. Currently there is one part left and I wish my assignment can be 
ST12 This is because the amount of time for this assignment is not sufficient due to my potential problems. I will complete this assignment with the help of my course mate.

ST15 This is due to a sudden call from my sponsor to attend a camp where the attendance is compulsory. Therefore, I would like to request for you to postpone the deadline to a few days after I came back

ST29 I was not able to submit it as per deadline because I was not in the university for the whole month as I was doing my internship program at Daikin Industries

ST39 I wanted to inform you that I am not able to submit my assignment on time, because of I had lose my laptop yesterday and all my assignment which I have done all lose already.

From the above examples, it is noted there is almost no appeal to pathos as the students were explaining their reasons for being late in submission before the deadline. The reasons such as 'most of the tests are carried out this week and I'm not able to revise and complete the assignment at the same time', 'not sufficient due to my potential problems', 'I will complete this assignment with the help of my course mate', 'because I was not in the university for the whole month as I was doing my internship program at Daikin Industries', or 'a sudden call from my sponsor to attend a camp where the attendance is compulsory' have very little emotion in them. For ST7, the reason given sounds more like an excuse than an appeal to emotion. ST7 may be stressed out due to assignments all being in the same week, but this may not classify as an emotional expression and was unrelated to the instructor. ST15 explained an unforeseen circumstance, but again, this may not relate to the instructor's emotions as it was unexpected and not a personal issue. ST12 offered a reason about 'potential problems'. The lack of details and structure of this reason make it difficult to be perceived from the emotional perspective. The students were not able to convince the instructor, which could have resulted in failing to get the extension.

Examples of appeals to logos are found in Excerpt 5.

\section{Excerpt 5}

ST1 I was in hurry last week and I didn't realise that the deadline was soon to end. I had an emergency since my grandma was not feeling well and my whole family was really in a panic situation.

ST9 This is because my grandmother has passed away in this morning and I have to skip class to attend her funeral for this coming 5 days.

ST17 I am sorry that I am not able to submit assignment as per deadline as my grandmother passed away this morning which I have to rush back to hometown for her funeral.

ST26 My home in Penang be in flood. My mother where live on her own got no one to take care of her and I cannot turn blind eye towards her

ST38 I wanted to inform you that I am not able to submit my assignment on time, because of I had lose my laptop yesterday and all my assignment which I have done all lose already.

The examples in Excerpt 5 are prime displays of strong appeals to logos being incorporated in the students' emails. Expressions such as 'I had an emergency since my grandma was not feeling well and my whole family was really in a panic situation', 'and I have to skip class to attend her funeral for this coming 5 days', and 'I have to rush back to hometown for her funeral' were used. ST1 explains how the family was 'in a panic situation' which is the obvious reaction of trepidation for the family member. ST9 also talks about the passing away of the grandmother whereby she had to 'skip class to attend her funeral'. This was a top priority for the student, and it is logical that she gave priority to her family's predicament. Similarly, in ST17's case, the student also needed to attend a funeral and had to 'rush back to hometown'. The student was worried and in a hurry to get home so that he could be with his family. All these reasons appeal strongly to logic, are very convincing, and place no doubt for the instructor in agreeing to an extension of the deadline. 
Excerpt 6, below, contains weak appeals to logos.

Excerpt 6

ST12 This is because the amount of time for this assignment is not sufficient due to my potential problems. I will complete this assignment with the help of my course mate.

ST14 Sir, I'm sorry to tell you that I can't submit my assignment before the deadline because my little brother was seriously ill and hospitalized recently. So, I had to take a good care of my little brother. I didn't have time to complete my assignment.

ST22 I have no idea how to start it. Would it be possible for Sir to Postpone the deadline so I can come out with a better idea on how to do my assignment and able to submit it on time?

ST38 I wanted to inform you that I am not able to submit my assignment on time, because of I had lose my laptop yesterday and all my assignment which I have done all lose already.

The examples here show weak appeals to logos and are very unprofessional, which is evident in the expressions such as 'not sufficient due to my potential problems', 'I will complete this assignment with the help of my course mate', 'I have no idea how to start it ... deadline so I can come out with a better idea', and 'I lost my laptop yesterday and all my assignment which I have done all lost already'. ST12 talked about 'potential problems' but this is vague and incomprehensible as there could be many problems the student might be dealing with. Moreover, the student said that the assignment could be completed with the 'help of my course mate'. This appeals poorly to logic if he/she says he/she needs the help of a course mate as it seems as though he/she was talking from both ends of a phone conversation. ST22 said he/she had 'no idea how to start it'. If this was the case, the student should have approached the instructor earlier and not right before the deadline. This shows that the student was simply procrastinating about his/her work by giving false excuses. Lastly, ST38 was talking about his/her missing laptop. It may be assumed that all his/her work and files were on the laptop and it did get lost, but the fact that it got lost right before the deadline was not a mere coincidence and was simply used as an excuse. In hindsight, the student should have kept his/her work and files backed up to a pen drive or other devices. In the end, the students could fail to convince the instructor and not get their extensions.

The results of this study on rhetorical appeals in students' persuasive email writing have revealed some interesting findings. When students were asked to write a persuasive email to their instructor for an extension, some students attempted to use Aristotle's rhetorical appeals, but most of them only employed one type of appeal in their requests. Ultimately, using more than one type of appeal may be more persuasive because if one strategy does not work, another might. However, this was not the case. The table below summarises the findings.

Table 2: Persuasive phrases in strong and weak appeals to ethos, logos and pathos

\begin{tabular}{lll}
\hline Appeal & Strong phrases & Weak phrases \\
\hline Ethos & $\begin{array}{l}\text {..I would humbly ask for you to postpone } \\
\text { the deadline... }\end{array}$ & $\begin{array}{l}\text {... have no idea how to start } \\
\text { it... }\end{array}$ \\
...could you please kindly... & $\begin{array}{l}\text {..not sufficient due to my } \\
\text { potential problems... }\end{array}$ \\
& ..I seek your sympathise... \\
...I would favourably request... & ...I want to ask you to... \\
& ...help of my course mate... \\
\hline
\end{tabular}


DOI: https://doi.org/10.47405/mjssh.v5i4.386

\begin{tabular}{|c|c|c|}
\hline \multirow[t]{2}{*}{ Logos } & $\begin{array}{l}\text {...I had an emergency since my grandma } \\
\text { was not feeling well and my whole family } \\
\text { was really in a panic situation... }\end{array}$ & $\begin{array}{l}\text {...not sufficient due to my } \\
\text { potential problems... }\end{array}$ \\
\hline & $\begin{array}{l}\text {...and I have to skip class to attend her } \\
\text { funeral for this coming } 5 \text { days... } \\
\text {... which I have to rush back to hometown } \\
\text { for her funeral... } \\
\text {...because of I had lose my laptop } \\
\text { yesterday and all my assignment which I } \\
\text { have done all lose already... }\end{array}$ & $\begin{array}{l}\text {... so, I had to take a good care } \\
\text { of my little brother. I didn't } \\
\text { have time to complete my } \\
\text { assignment... } \\
\text {...I have no idea how to start } \\
\text { it... } \\
\ldots \text { with the help of my course } \\
\text { mate... }\end{array}$ \\
\hline Pathos & $\begin{array}{l}\text {...gone through a surgery and need to take } \\
\text { a rest for a week at the hospital... } \\
\text {...this is because my grandmother has } \\
\text { passed away... } \\
\text {...got no one to take care of her and I } \\
\text { cannot turn blind eye towards her... } \\
\text {... serious accident last week and fractured } \\
\text { my right shoulder... }\end{array}$ & $\begin{array}{l}\text {... sudden call from my } \\
\text { sponsor to attend a camp } \\
\text { where the attendance is } \\
\text { compulsory... } \\
\text {...because I was not in the } \\
\text { university for the whole } \\
\text { month as I was doing my } \\
\text { internship program at Daikin } \\
\text { Industries... } \\
\text {...I'm not able to revise and } \\
\text { complete the assignment at } \\
\text { the same time... } \\
\text {...not sufficient due to my } \\
\text { potential problems... }\end{array}$ \\
\hline
\end{tabular}

Table 2 shows the summary of strong and weak persuasive phrases using appeals to ethos, logos and pathos by the engineering students. The weak phrases would be considered inappropriate in formal emails. The strong appeals could be used in professional settings, showing strong credibility, emotion and logic. According to Aristotle (1954), there were no examples given for strong and weak phrases in his definitions of those strategies. However, Bachman and Palmer (2010) mentioned that the use of words or phrases, depending on their context, should be more pleasant in professional settings, which would create a highly persuasive effect on the listener or reader to agree with that for which the speaker or writer asked. Therefore, Bachman and Palmer (2010) appear in agreement with Aristotle's (1954) views on rhetorical appeals to ethos, pathos and logos.

Another aspect of using these phrases as reasoning to ask for postponement of a deadline was that students lacked English proficiency. Due to the lack of proficiency, weak phrases were used in their appeals. For instance, 'I have no idea how to start' and 'I want to ask you', were used as appeals to logos, which is not necessarily wrong; however, those phrases would not be suitable according to Allwood (1956) and Bachman and Palmer (2010) as appropriate words or phrases should be uttered to enhance the credibility of the speaker, and this would be more convincing to the listener either in spoken or written language, as mentioned above. Ting's (2018) research on informal requests revealed the use of a few appeals to ethos, pathos and logos in her students' requests to allow them to leave class early, which included (i) ' $\mathrm{Dr}$, I think we should end class early today because the tutorial room is too hot. There is accumulation of carbon dioxide here which rise the temperature I need to see my supervisor' and (ii) 'I have a full timetable on Tuesday start from 8 am to $6 \mathrm{pm}$ except $2 \mathrm{pm}$ to $4 \mathrm{pm}$ free. Could you please end the class earlier so that I have time to have my lunch before $12 \mathrm{pm}$ class start?' Although these utterances were suitable for informal requests, they were not suitable for the students in the more formal context of the present study. As the present research focused on the 
classroom setting and the task was persuasive email, writing to postpone the deadline of assignment submission should appropriately done in a formal manner. It was concluded that since the students were millennials (Nicks, 2015), who are immersed in social media, who are inclined in using colloquial words could have affected their abilities to have the sensibility of their requests and their own credibility in persuasive requests. However, some utterances with strong phrases such as 'I would humbly ask for you to postpone the deadline', 'could you please kindly', 'I seek your sympathies', 'I would favourably request', which fall under the category of ethos, show that the openings of the students' emails were very convincing and created a favourable impression on the reader, which was especially true for the lecturers in this study.

Apart from the above, interestingly the lecturers noted that during the students' group discussions, the students tend to use direct phrases seems to be inappropriate or harsh, especially when they were in the midst of making decisions, such as 'I don't like your ideas', 'err, I hate your view la', 'can you please, shut your gop' and 'please stop it', 'I don't like ideas'. These were insensitive phrases and not persuasive in conveying disinterest in the ideas being offered. Perhaps they should have said 'I like your ideas but I would suggest...' as Aristotle (1954) suggested that persuasive intent should be accomplished with sensitive and convincing phrases presented in a respectful manner to win acceptance of a person's ideas or opinions without creating disheartening emotional effects which could negatively affect the addressee.

\section{Limitations and Future Research Directions}

Although the research provides some important insights on practical and written persuasion, the limitations of the study should be mentioned. Interviews with students and audio and video recordings were not allowed in the classes for this study, which limited the extent of the transcription of interviews as well as the observation of participants' behavioural attitudes and expressions during classroom activities. If audio and video recording had been allowed in the interviews, the data would have been richer and more authentic and contributed more significantly in terms of findings.

Further research could be conducted by incorporating the linguistic aspect of communicative strategies theory and the psycholinguistic or psychological aspects of cognitive emotional theory to understand the attitudes, thoughts and feelings that influenced the manner of persuasive spoken or written communication to determine cognitive and behavioural processes in social situations important for enhancing university and workplace communication among students as well as working professionals. As for the working staff, research should explore how various levels of management staff differ in their writing of email to be sent to customers and their use of persuasive skills and how this is different compared to students' writing of similar email. Such research would provide evidence-based insight into spoken or written persuasive communication skills for the workplace, which could then be integrated into the students' curriculum.

\section{Conclusion}

It is important to state that the purpose of human communication is generally to help in establishing and maintaining the collaborative relationships between interlocutors through speech and/or writing, which could take place in various settings such as those found in business and administration. It is also common these days for people who use social media like WhatsApp, Instagram, and Facebook to make use of colloquial words in their interactions with friends and family, but the reverse is the case in professional settings (Nicks, 2015). The influence of immersion into these forms of social media has affected people's persuasive skills, including those needed for convincing others to follow a course of action, agree to do something, make a commitment or purchase products.

In professional settings, however, people use persuasive words appropriate to situations such as those used in the workplace between managers and staff, at job interviews based on behavioural interview questions, at hotels between customers and receptionists or in restaurants between customers and 
servers. The reason for the usage of situationally appropriate persuasive words is that it helps to establish seriousness in their communication depending on the context. The choice of words may also enhance the credibility, emotion and logic of written language. Writing tasks performed in workplace communication often entail convincing staff members to follow a course of action. Employers therefore give significant attention to persuasive skills as they have a huge impact on many aspects of the workplace leading to increased productivity. Thus, written persuasive skills should be nurtured before seeking employment, and this is where educational intuitions could play a vital role in educating students in the art of being persuasive.

It is required that ethos, pathos and logos be used in a reasonable way in demonstrating the strong art of persuasion. Thus, it is essential that Aristotelian rhetorical theory be emphasised in schools or highereducation classroom contexts, especially with regard to persuasive business email writing so that students may realise that credibility, emotion and logic are equally important in persuasive email writing, especially in convincing a person to do something.

\section{References}

Abdul Rashid, R., Jamal, S.N., Ibrahim, N.S.N., Yunus, K., Azmi, N.J., Anas, M. \& Mohamed, S.B. (2016). Rhetoric and health: How Fitness Trainers Persuade Public on Social Networking Site. Man In India, 96(11), 4673-4679.

Amossy, R. (2000). L'Argumentation dans le discours. Paris : Nathan Univertsty.

Androniciuc, A.I. (2016). Using social media in political campaigns. Evidence from Romania. SEA: Practical Application of Science, 4(1).

Allwood, J. (1976). Linguistic communication as action and cooperation. Gothenburg Monographs in Linguistics 2. University of Goteborg, Department of Linguistics, pp. 1-257.

Al-Momani, K.R. (2014). Strategies of persuasion in letters of complaint in academic context: the case of Jordanian University students' Complaints. Discourse Studies, 16(6), 705-728.

Atkinson, P. \& Hammersley, M. (1994). Ethnography and participant observation. In NK Denzin and YS Lincoln (Eds.) Handbook of Qualitative Research (pp. 248-261). Thousand Oaks, CA: Sage Publication.

Aristotle. (1954). On rhetoric (trans. W. Rhys Roberts). London: Random House.

Aristotle Rhetoric (1959). Edited by Ross, W.D. Oxford: Oxford UP.

Arnold, V.D. (1985). The Importance of pathos in persuasive appeals. Bulletin of the association for business communication, 48(4), 26-27.

Bachman, L. F., \& Palmer, A. S. (2010). Language assessment in practice. Oxford: Oxford University Press.

Beck, C.E. \& Wegner, K. (1992). Toward a rhetoric of technical proposals: ethos and audience analysis. Technical Communication, 39(1), 122-127.

Berg, B. L. \& Lune, H.(2012). Qualitative research methods for the social sciences (8th ed.). Boston. p. 3. ISBN 9780205809387. OCLC 732318614.

Berlanga, I., Garcia-Garcia, F., \& Victoria, J. (2013). Ethos, pathos and logos in facebook. user networking: New Rhetor of the 21st Century. Comunicar, 21(41), 52. Brown, J., \&

Black, E. (1970). The second persona. Quarterly Journal of Speech, 56,109-119. http://dx.doi.org/10.1080/00335637009382992

Burke, K. (1969). A Rhetoric of motives. Berkley, CA: University of California Press.

Chakorn, O. O. (2006). Persuasive and politeness strategies in cross-cultural letters of request in the Thai business context. Journal of Asian Pacific Communication, 16(1), 103-146.

Charland, M. (1987). Constitute rhetoric: The case of the 'puple quebecois'. Quarterly Journal of Speech, 73, 133-150. http://dx.doi.org/10.1080/00335638709383799

Christina, C. (2018, March 4). Varsity aims to boost grads' employability. The Star, Retrived March 8, 2018, from https://www.thestar.com.my/news/nation/2018/03/04/varsity-aims-to-boost-gradsemployability/

Creswell, J. (2014). Research design: Qualitative, quantitative, and mixed methods approaches (4th ed.) SAGE Publications, Inc 
Connors, R. J. (1979). The differences between speech and writing: ethos, pathos, and logos. college composition and communication, 30(3), 285-290.

Demirdugen, U. D. (2010). The roots of research in (political) persuasion: ethos, pathos, logos and the yale studies of persuasive communications. International Journal of Social Inquiry, 3(1), 189201.

Emanuel, B., Rodrigues, C. \& Martins, M. (2015, August). Rhetoric of interaction: analysis of pathos. in international conference of design, user experience, and usability (pp. 417-427). Springer International Publishing.

Fife, J.M. (2010). Using facebook to teach rhetorical analysis. Pedagogy, 10(3), 555562.

Frank, S. (2018). Truth value, Trump, and benign lies at the closing of the Gutenberg Parenthesis. Communication Research and 2206-3374. doi:https://doi.org/10.1080/22041451.2018.1434790

Gabrielsen, J. \& Christiansen, T. J. (2010). The Power of Speech. Denmark: Gyldendal.

Graham, S., K.R. Harris, \& Mason,L. (2005). Improving the writing performance, knowledge and selfefficacy of struggling young writers: The effects: of self-regulated strategy development. Contemporary Educational Psychol., 30: 207-241.

Hayes, A. F., \& Krippendorff, K. (2007). Answering the call for a standard reliability measure for coding data. Communication Methods and Measures, 1(1), 77-89.

Horovitz,B.( 4 May, 2012). After Gen X, Millenial, what should next generation be. USA Today.

Hovland, C. I., Lumsdaine. A. A. \& Sheffield, E. D. (1949). Experiments on mass communication. Princeton: Princeton University Press.

Higgins, C. \& Walker, R. (2012). Ethos, logos, pathos: strategies of persuasion in social/environmental reports. Accounting Forum, 36, 194-208.

Jackson, S. L. (2012). Research methods statistics. (4 $4^{\text {th }}$ ed.) Chigago,NY:WadsworthCengage Learning.

Jennifer, L. L. \& Jorge,V. (2018). Affective Effects of Offering Options on Persuasiveness of Fear Appeals, Journal of Promotion Management, 0,(0).1-15.

JobStreet (2013). Survey Retrieved September 26, 2015, from http://www.digitalnewsasia.com/digitaleconomy/comms-english-skills-more-important-for-employers-jobstreet-survey

JobStreet (2014). Survey, Retrieved December 30, 2016, from http://www.digitalnewsasia.com/digitaltops five reasons fresh graduated don't get hired.

Jorgensen, D. L. (1989). Participant observation: A methodology for human studies. newbury park, CA: Sage Publications.

Ledgerwood, A., Chaiken S., Gruenfeld, D. H. \& C.H. Judd (2006). "Changing minds: persuasion in negotiation and conflict resolution". In Deutsch, M., Coleman, P.T., \& E. C. Marcus (eds.) The Handbook of Conflict Resolution: Theory and Practice. San Fransisco: Jossey Bass.

Kagermann, H., Wahlster,W. \& Helbig, J. (2013): Recommendations for implementing the strategic initiative Industry 4.0 (Eds.), Final report of the industry 4.0 Working Group.

Kamimura, T. \& Oi, K. (1998). Argumentative Strategies In American And Japanese English. World Englishes, 17(3), 307-323.

Koo, C., Gretzel, U., Hunter, W. C., \& Chung, N. (2015). The role of IT in tourism. Asia Pacific Journal Information Systems, 25, 99-104.

Larson, C. U. (1992). Persuasion: Reception and responsibility. Belmont: Wadsworth.

Lisa, L. (2016). Stunning statistics for persuasive speaking. Communication Teacher, 1740-4630. http://dx.doi.org/10.1080/17404622.2016.1244346

Manning,T. (2012). The art of successful skills: Seven skills you need you get your points across effectively. Industrial and Commercial Training, 44(3), 150-158.

Mori, K. (2016, November 14-15). Analysis of the discourse of diplomatic conflict at the UN: Application of ethos, pathos, logos. Proceedings of 12th International Conference on Humanities \& Social Sciences 2016 (IC-HUSO 2016), Faculty of Humanities and Social Sciences, Khon Kaen University, Thailand.

Mshvenieradze, T. (2013). Logos, ethos and pathos in political discourse. Theory and Practice in Language Studies, 3(11), 1939-1945.

Nair, S. R. \& Ndubisi, N. O. (2013). Entrepreneurial values, environmental marketing and customer satisfaction: Conceptualisation and propositions. Enterprise Development in SMEs and Entrepreneurial Firms: Dynamic Processes. 257-269 
DOI: https://doi.org/10.47405/mjssh.v5i4.386

Naksawat, C., Akkakoson, S. \& Loi, C.K. (2016). Persuasion Strategies: Negative Forces in Scam Emails. GEMA Online ${ }^{\circledR}$ Journal of Language Studies, 16(1), 1-17.

Nicks, D. (2015). Hotels Airbnb competition report. Times Magazine.Retrived December 01, 2017, from, http://time.com/ money/4117068/hotels-airbnb-competition-report/.

Peck, B.S. (2018, January 24). Industry 4.0 success depends on key factors. Retrieved March 09, 2018 from https://www.thestar.com.my/news/nation/2018/01/24/industry-40-success-depends-onkey-factors/

Raslie, H., Pit S. \& Ting,S.H. (2016). Millennials' expectations of life at the university and the workplace: A Malaysian perspective. International Journal of Education, 8(3), 71-84.

Rebecca,R.(2016, June 12). English skills vital for all. The Star. Retrieved June 13, 2016, from http://www.thestar.com.my/news/education/2016/06/12/english-skills-vital-for-all/

Robberson, M. R. \& Rogers, R. W. (1988). Beyond fear appeals: negative and positive persuasive appeals to health and self-esteem. Journal of Applied Social Psychology, 18(3), 277-287.

Shahrbanou, G.A., Helen, T., Ain,N.A, Sharon, S. \& Lee,G.I. (2019).Introduction chapter of traditional and article-based theses: A comparison of rhetorical structures and linguistic realisations, GEMA Online ${ }^{\circledR}$ Journal of Language Studies, 19(1), 116-135.

Stacks, D. \& salwen, m. (2009). An integrated approach to communication theory and research. New York: Routledge.

Sung-Byung,Y., Hanna,L., Kyungmin,L. \& Chulmo,K.(2018). The application of Aristotle's rhetorical theory to the sharing economy: An empirical study of Airbnb. Journal of Travel \& Tourism Marketing, 35 (7), 1-13.

Ting, S.H. \& Collin,J. (2018). Framing of disease risk messages in airport banners. International Journal of Law, Government and Communication, 2(6), 63-75.

Ting,S.H. (2018). Ethos, logos and pathos in university students' informal requests. GEMA Online ${ }^{\circledR}$ Journal of Language Studies, 18(1), 234-251.

Uysal, H. H. (2012). Argumentation Across L1 and L2 Writing: Exploring Cultural Influences and Transfer Issues. Vigo International Journal of Applied Linguistics (VIAL),9,133-159.

Vawn, H. (15 Feb, 2019).Ethos, pathos, logos: How rhetoric can improve your teaching, Retrieved May 16, 2019 from https://tophat.com/blog/ethos-pathos-logos/

Winn, W. (2000). The persuasive power of pathos in e-commerce web design: A new area for research. In professional communication conference, 2000. Proceedings of 2000 Joint IEEE International and 18th Annual Conference on Computer Documentation (IPCC/SIGDOC 2000),(pp. 155-160). IEEE. 